\title{
Ocena tendencji współczesnej ewolucji wybranego fragmentu koryta dolnego Bugu na podstawie materiałów kartograficznych i teledetekcyjnych
}

\author{
Channel evolution trends of the selected section of the Bug River middle reach based on the \\ archival maps and remote sensing material
}

\author{
Piotr Ostrowski, Karol Kaszyński \\ Katedra Geoinżynierii, Szkoła Główna Gospodarstwa Wiejskiegowwarszawie, piotr_ostrowski@sggw.pl
}

Zarys treści: W artykule przedstawiono ocenę tendencji zmian morfologii strefy korytowej Bugu na odcinku między 12. a 22. km rzeki (Dolina Dolnego Bugu). Analizę wykonano w środowisku GIS na podstawie porównania materiałów kartograficznych i teledetekcyjnych z okresu od 1891 do 2013 r. Poprzez morfologię strefy korytowej rozumiano przebieg koryta (jego układ w planie) oraz układ wypełnionych wodą form - głównie zanikających koryt bocznych, rynien erozyjnych przepływów wezbraniowych oraz starorzeczy w proksymalnej części równi zalewowej.

Słowa kluczowe: morfologia koryta, Dolina Dolnego Bugu, GIS, teledetekcja

\begin{abstract}
Paper contains an analysis of trends in morphology changes through the Bug section between 12 and $22 \mathrm{~km}$ of its course (within the valley of the lower Bug). Performed in GIS environment analysis was based on maps and remote sensing materials that cover the period of time from 1891 to 2013. The channel morphology is defined here as the channel course (its planform) with a system of filled with water depressions (side arms, erosional pathways of overbank flow and oxbow lakes) located in proximal floodplain.
\end{abstract}

Key words: channel morphology, Bug valley (Dolina Dolnego Bugu), GIS, remote sensing

\section{Wprowadzenie}

Rozległe doliny dużych rzek Niżu Polskiego są obszarami z jednej strony cennymi przyrodniczo (korytarze ekologiczne, obszary Natura 2000), z drugiej zaś w związku z postępującą antropopresją - coraz ważniejszymi gospodarczo. Są to także obszary o największej na Niżu Polskim morfodynamice. Procesy kształtujące rzeźbę dolin rzecznych przebiegają często gwałtownie (wezbrania), a ich efekty są zauważalne nawet w niewielkich przedziałach czasowych (Falkowski, Ostrowski 2010, Wierzbicki i in. 2013). W przypadku szeroko pojętego zagospodarowania dolin rzecznych trzeba uwzględniać naturalne, a zwłaszcza geologiczne i geomorfologiczne uwarunkowania tych procesów (Falkowski 2006). W miarę możliwości podejmować należy także próby określania tendencji ich dalszego przebiegu.

Obecnie można dysponować ogromną ilością archiwalnych, często ogólnodostępnych (również online) danych, które mają lub którym przypisać można atrybuty georeferencyjne. Do dyspozycji są także skuteczne narzędzia informatyczne do ich wspólnej analizy na platformie geoinformacyjnej (GIS - ang. Geographical Information Systems) oraz technologie umożliwiające weryfikację jej wyników. Do tych ostatnich należą między innymi komercyjne wysokorozdzielcze systemy satelitarne, dostosowane do pozyskiwania danych geoprzestrzennych systemy bezpilotowe, ALS (ang. Airborne 
Laser Scanning) czy szybko rozwijający się TLS (ang. Terrestrial Laser Scanning). W artykule przedstawiono przykład takiej analizy w celu zbadania przebiegu współczesnych procesów geomorfologicznych zachodzących w Dolinie Dolnego Bugu.

\section{Cel pracy}

Celem pracy była identyfikacja współczesnych zmian morfologii wybranego odcinka strefy korytowej Bugu na podstawie ogólnodostępnych materiałów kartograficznych i teledetekcyjnych w możliwie jak najdłuższym przedziale czasowym. Poprzez morfologię strefy korytowej rozumiano głównie przebieg koryta (jego układ w planie) oraz układ wypełnionych wodą form - głównie zanikających koryt bocznych, rynien erozyjnych przepływów wezbraniowych oraz starorzeczy w proksymalnej części równi zalewowej. Założeniem autorów była analiza tempa oraz skali tych zmian we fragmencie doliny, gdzie występowały w ograniczonym zakresie lub nie występowały sztuczne elementy zaburzające naturalny przebieg procesów korytowych.

Dodatkowym celem pracy była próba określenia kierunków dalszej ewolucji strefy korytowej badanego odcinka rzeki. Informacje takie uznać należy za użyteczne w procesach decyzyjnych związanych z planowaniem zagospodarowania przestrzennego doliny, ochroną przeciw- powodziową, a także ochroną występujących na badanym obszarze cennych przyrodniczo siedlisk.

Podjęte badania miały charakter wstępnego rozpoznania, które miało na celu właściwe zaplanowanie formy i zakresu szczegółowych badań dna Doliny Dolnego Bugu (między innymi geologicznych, geomorfologicznych, hydrograficznych, sedymentologicznych, palinologicznych oraz teledetekcyjnych) w najbliższej przyszłości.

\section{Obszar badań}

Obszar badań jest zlokalizowany w południowo-zachodniej części Doliny Dolnego Bugu (Kondracki 2009) i ma przebieg zbliżony do równoleżnikowego. Obejmuje on fragment rzeki w jej dolnym biegu, nieco powyżej ujścia do Jeziora Zegrzyńskiego - sztucznego zbiornika, który powstał w wyniku spiętrzenia wód Narwi i Bugu stopniem piętrzącym w Dębe. Szczegółowej analizie poddano fragment dna doliny między 12. a 22. km biegu rzeki (ryc. 1). Wyróżnić tu można dwa odcinki, zróżnicowane pod względem stopnia przekształceń antropogenicznych. Pierwszy z nich (A), między 12. a 17. km, został częściowo uregulowany w latach 60 . ubiegłego wieku i znajduje się w końcowej strefie oddziaływania cofki Jeziora Zegrzyńskiego (Gromiec 2003). Podkreślić trzeba jednak, że budowle regulacyjne wykonane ponad pół wieku

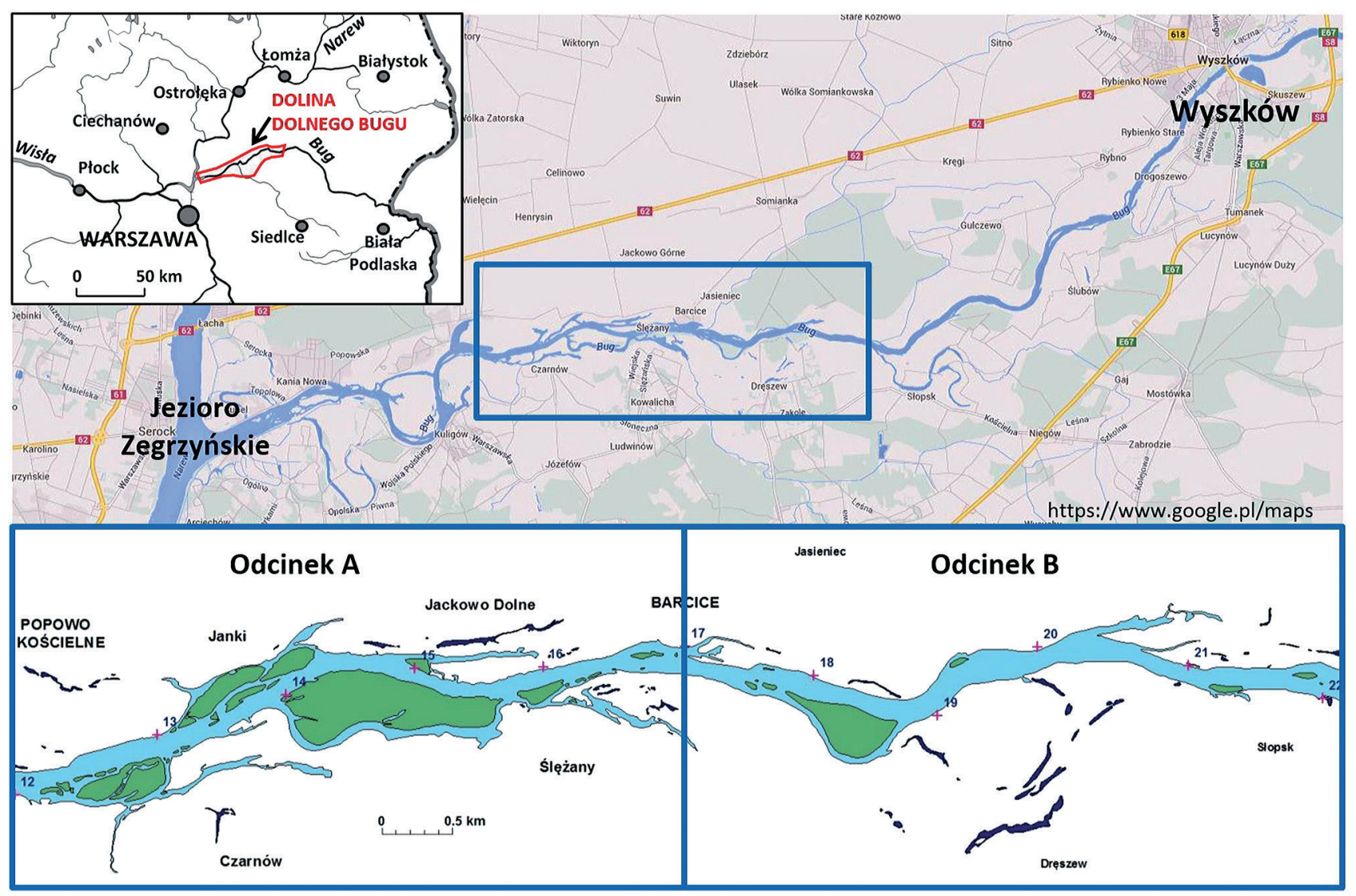

Ryc. 1. Położenie obszaru badań

Fig. 1. Location of the study area 
temu, w mało trwałej technologii faszynowo-kamiennej, nie podlegały konserwacji ani remontom od chwili powstania. Dlatego też znaczna ich część została niemal całkowicie zniszczona lub uległa kolmatacji (Zieliński, Narowski 2003). Drugi odcinek (B), między 17. a 22. km, ma charakter zbliżony do naturalnego. Nie występuje na nim zabudowa hydrotechniczna koryta, przeprawy mostowe ani ograniczające powierzchnię równi zalewowej wały przeciwpowodziowe. Dużym stopniem naturalności charakteryzują się także występujące tu ekosystemy, co zadecydowało o objęciu tego obszaru szczególną ochroną (Urban, Wójciak 2003, Wojciechowski 2003).

Mimo że ujściowy odcinek Bugu ze względu na swój charakter wskazywany jest jako bardzo interesujący dla badań naturalnych tendencji ewolucji koryta (Falkowski 1971, Mojski 2005), w lieraturze nie znaleziono tego typu opracowań. Zmiany układu koryta w ujściowej strefie Bugu analizował jedynie Magnuszewski (2011), porównując dane topograficzne sprzed powstania Jeziora Zegrzyńskiego z ortofotomapą z 2010 r., lecz analiza ta ograniczała się do $0 .-10$. $\mathrm{km}$.

\section{Materiały i metody}

Podstawą do analizy zmian morfologii strefy korytowej dolnego Bugu było porównanie dostępnych materiałów kartograficznych i teledetekcyjnych obejmujących badany fragment doliny. Założeniem autorów była analiza materiałów w jak najszerszym przedziale czasowym.
Za przydatne do prowadzonych prac uznano materiały w skalach 1:25 000 i większych. Konieczność wspólnej analizy przestrzennej danych (głównie map topograficznych i ortofotomap) wykonanych w różnych skalach, układach współrzędnych i różnymi technikami, wymagała zastosowania technologii GIS.

W pracy analizowano mapy topograficzne $\mathrm{z}$ lat 1933 , 1940, 1974, 1991 oraz ortofotomapę wykonaną na podstawie zdjęć lotniczych z 2010 r. Najstarszym materiałem kartograficznym była Mapa Szczegółowa Polski w skali 1:25 000 wydana w 1933 r. przez Wojskowy Instytut Geograficzny (WIG). Mapa ta wykonana została na podstawie zdjęcia z 1891 r., dlatego też uznano, że odzwierciedla układ strefy korytowej z tego roku. Kolejnym archiwalnym materiałem była niemiecka mapa topograficzna typu Meßtischblatt wydana w 1940 r. przez Urząd Rzeszy. Przedstawia ona treść kartograficzną z roku 1934. Mapy z lat 1933 i 1940 pozyskano w postaci cyfrowych skanów o rozdzielczości 400 dpi za pośrednictwem serwisu internetowego Mapster z Archiwum Map Wojskowego Instytutu Geograficznego 1919-1939 (Projekt mapywig.org 2014). Mapy topograficzne z lat 1974 i 1991 oraz ortofotomapę z roku 2010 pozyskano z użyciem standardów WMS (ang. Web Map Service) z Geoportalu Krajowego (GUGiK 2013).

Wszystkie dane rastrowe umieszczono w bazie danych GIS w postaci odrębnych warstw informacyjnych. W celu wspólnej analizy zostały one zarejestrowane lub przekonwertowane do PUWG 1992 (ryc. 2). Zestawienie analizowanych materiałów rastrowych zawiera tabela 1 .

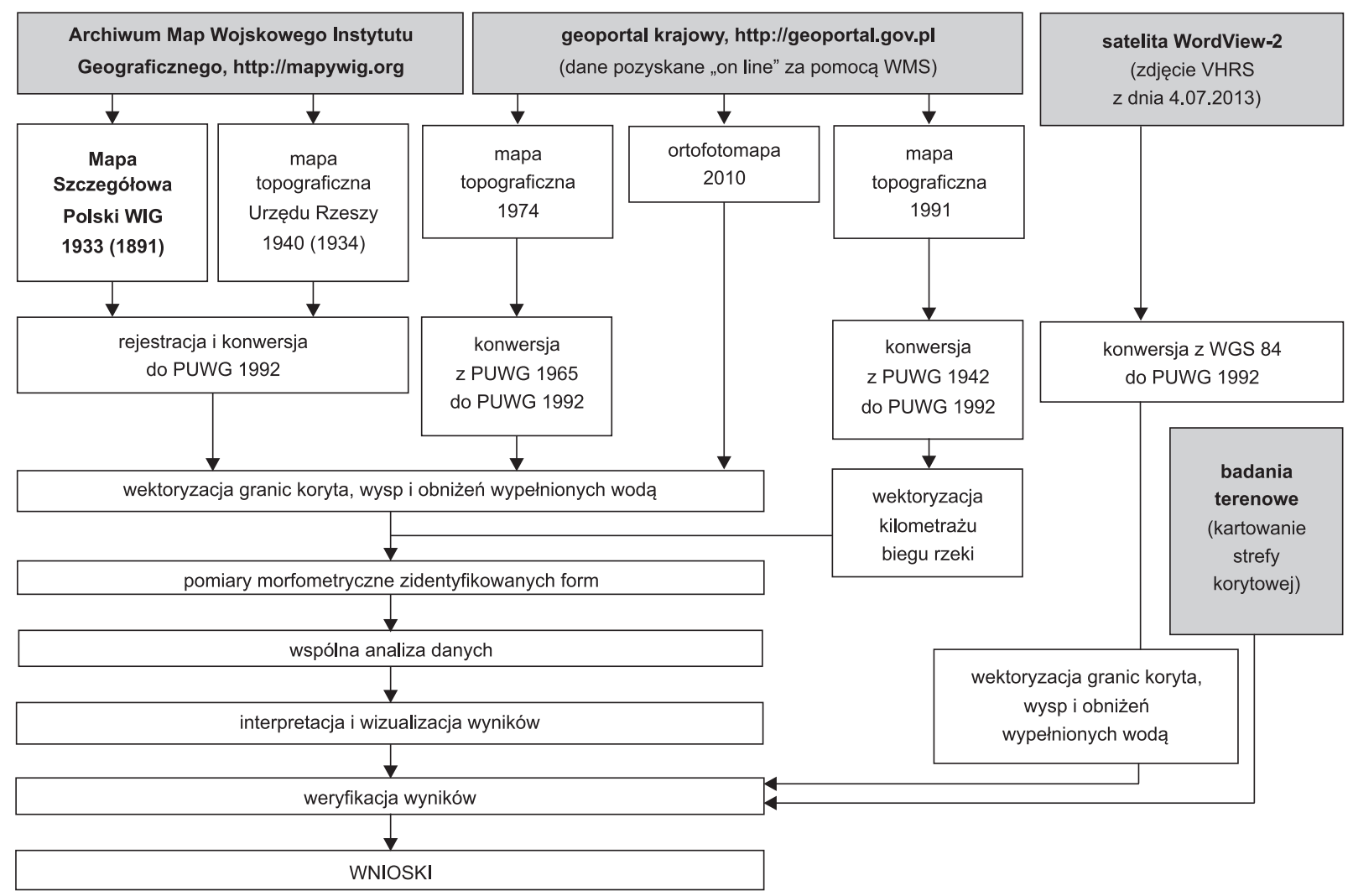

Ryc. 2. Uproszczony schemat prowadzonych prac badawczych - kolorem szarym zaznaczono źródła danych

Fig. 2. Simplified scheme of research - grey colour indicates data source 
Tabela 1. Zestawienie rastrowych materiałów kartograficznych i teledetekcyjnych

Table 1. Summary raster cartographic and remote sensing materials

\begin{tabular}{|c|c|c|c|c|c|}
\hline Rodzaj materiału & Rok & Godło & Skala & $\begin{array}{c}\text { Układ } \\
\text { współrzędnych }\end{array}$ & Uwagi \\
\hline Mapa topograficzna & $\begin{array}{c}1933 \\
(1891)^{*}\end{array}$ & PAS 38 - SŁUP 32-1 & $1: 25000$ & 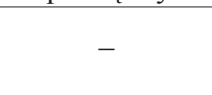 & $\begin{array}{l}\text { Mapa Szczegółowa Polski wykonana przez } \\
\text { WIG na podstawie zdjęcia z } 1891 \text { r. }\end{array}$ \\
\hline Mapa topograficzna & $\begin{array}{c}1940 \\
(1934)^{*}\end{array}$ & P3832 J Sominka & $1: 25000$ & - & $\begin{array}{c}\text { mapa wydana w } 1940 \text { r. przez Urząd } \\
\text { Rzeszy na podstawie mapy topograficznej } \\
\text { WIG z } 1934 \text { r. }\end{array}$ \\
\hline Mapa topograficzna & 1974 & 263:21 Somianka & $1: 25000$ & 1965 & - \\
\hline Mapa topograficzna & 1991 & $\begin{array}{l}\text { N-34-127-A-d4 Ludwików } \\
\text { N-34-127-B-c3 Dręszew } \\
\text { N-34-127-B-c4 Słopsk }\end{array}$ & $1: 10000$ & 1942 & - \\
\hline Ortofotomapa & 2010 & $\begin{array}{l}\text { N-34-127-A } \\
\text { N-34-127-B }\end{array}$ & $\begin{array}{l}1: 5000 \\
1: 5000\end{array}$ & $\begin{array}{l}1992 \\
1992\end{array}$ & zobrazowanie wykonane $21.06 .2010 \mathrm{r}$. \\
\hline $\begin{array}{l}\text { Zdjęcie satelitarne } \\
\text { VHRS }\end{array}$ & 2013 & - & - & WGS 84 & $\begin{array}{c}\text { zobrazowanie wykonane } 4.07 .2013 \mathrm{r} \text {. } \\
\text { przez satelitę WorldView-2 }\end{array}$ \\
\hline
\end{tabular}

* w nawiasach podano rok aktualizacji treści topograficznej.

W następnym etapie prac na podstawie zarejestrowanych map topograficznych oraz ortofotomapy zdigitalizowano granice koryta Bugu, mezoform korytowych (wysp) oraz obniżeń wypełnionych wodą (głównie zanikających koryt bocznych, rynien erozyjnych przepływów wezbraniowych i starorzeczy). Wyniki tych prac zostały zapisane w postaci wektorowych warstw informacyjnych, które stanowily podstawę dalszych analiz. Prawidłowa klasyfikacja niektórych form rzeźby zarówno w przypadku topograficznych materiałów archiwalnych, jak i ortofotomapy wymagała przeprowadzenia rozpoznania terenowego. Rozpoznanie dotyczyło głównie starorzeczy, które na mapach topograficznych zaznaczone były podobnie jak wypełnione wodą erozyjne formy o innej genezie (np. rynny erozyjne przepływów wezbraniowych). Identyfikację dodatkowo utrudniał fakt, że formy te charakteryzowały się podobnymi cechami morfometrycznymi i obrazem (strukturą i teksturą) na zdjęciach satelitarnych. Badania terenowe przeprowadzono w lipcu 2013 r. Obejmowały one identyfikację starorzeczy, a $\mathrm{w}$ rejonie 21.-22. km dodatkowo kartowanie strefy korytowej Bugu. W czasie prac wykonano także dokumentację fotograficzną.

Jednym z podstawowych założeń badań była weryfikacja wyników analizy danych archiwalnych z wykorzystaniem aktualnych materiałów teledetekcyjnych. Dokonano jej na podstawie wysokorozdzielczego wielospektralnego zdjęcia satelitarnego (VHR - ang. Very High Resolution) wykonanego w lipcu 2013 r. przez satelitę WorldView-2. Satelita ten pozyskuje dane o rozdzielczości przestrzennej $0,5 .-0,6$. $\mathrm{m}$ w ośmiu zakresach spektralnych (kanałach). Wcześniejsze doświadczenia z interpretacją form rzeźby równi zalewowej Bugu oparte na wielospektralnych zdjęciach VHRS (Ostrowski 2011) pozwoliły uznać za najbardziej przydatną kompozycję barwną w barwach nienaturalnych (ang. false color composition) z uwzględnieniem bliskiej podczerwieni. Do analizy wybrano kompozycję złożoną z trzech kanałów - Green (510-580 nm), Red (630-690 nm) i Near-IR1
(770-895 nm). Dane źródłowe w formacie GeoTIFF 1.0 i układzie WGS 84 przeliczono do układu PUWG 1992 i umieszczono w bazie danych.

Szczegółowej analizie (fotointerpretacji manualnej) poddano fragmenty dwóch scen satelitarnych obejmujących swoim zasięgiem strefę korytową Bugu na odcinku od 16. do 23. km. Na podstawie zdjęć satelitarnych zidentyfikowano aktualny przebieg koryta, granice mezoform korytowych oraz form erozyjnych wypełnionych wodą w proksymalnej części równi zalewowej. Wyniki fotointerpretacji porównano $\mathrm{z}$ wynikami analizy materiałów archiwalnych.

Mimo zastosowania technologii GIS autorzy zdają sobie sprawę z ograniczeń prowadzonych analiz. Należy tu wymienić dwie podstawowe przyczyny:

- choć wszystkie materiały sporządzone zostały w podobnych i analizowane w tych samych skalach, to (zwłaszcza w przypadku map topograficznych) porównywano interpretację granic form wykonaną na podstawie pomiarów zmieniającymi się na przestrzeni ponad stu lat technikami, według różnych zaleceń i przez różnych autorów;

- interpretowane formy ze względu na położenie (proksymalna część równi zalewowej) i cechy morfometryczne (między innymi niewielkie różnice wysokości względnych) są bardzo „wrażliwe” na sytuację hydrologiczną; ich granice w znacznym stopniu determinuje stan wody w korycie w trakcie pozyskiwania informacji potrzebnych do wykonania map topograficznych lub ortofotomap.

W związku z tymi ograniczeniami, a także stosunkowo niewielką długością badanego odcinka (ok. $10 \mathrm{~km}$ ) do minimum ograniczono analizę ilościową zidentyfikowanych zmian, koncentrując się na opisie zaobserwowanych tendencji. Na podstawie wektorowych warstw informacyjnych dla całego badanego odcinka określono sumaryczną powierzchnię poszczególnych typów zidentyfikowanych form (koryta, wysp i obniżeń wypełnionych wodą) w poszczególnych latach oraz jej zmiany w trzech 
Tabela 2. Zmiana powierzchni wybranych form rzeźby na analizowanym fragmencie doliny Bugu (12.-22. km)

Table 2. Change of landforms area within analysed reach of the Bug river valley (12.-22. km)

\begin{tabular}{lrrrrrrrr}
\hline \multirow{2}{*}{ Rodzaj formy } & \multicolumn{4}{c}{ Powierzchnia w latach $\left[\mathrm{km}^{2}\right]$} & \multicolumn{3}{c}{ Zmiana powierzchni w latach [\%] } \\
\cline { 2 - 9 } & 1891 & 1934 & 1974 & 1991 & 2010 & $1891-1934$ & $1934-1974$ & $1974-2010$ \\
\hline koryto & 2,781 & 2,124 & 1,906 & 2,071 & 1,889 & $-23,6$ & $-10,3$ & $-0,9$ \\
wyspy* & 0,632 & 0,713 & 0,876 & 0,957 & 0,968 & 12,8 & 22,9 & 10,5 \\
obniżenia wypełnione wodą** & 0,253 & 0,191 & 0,221 & 0,153 & 0,149 & $-24,5$ & 15,7 & $-32,6$ \\
\hline
\end{tabular}

* sumaryczna powierzchnia wysp.

** sumaryczna powierzchnia koryt bocznych, rynien erozyjnych przepływów wezbraniowych i starorzeczy w proksymalnej części równi zalewowej.

zbliżonej długości przedziałach czasowych (w latach 1891-1934, 1934-1974, 1974-2010). Wyniki analizy ilościowej przedstawiono w tabeli 2.

W celu identyfikacji przestrzennej opisywanych zjawisk posłużono się kilometrażem rzeki z map topograficznych w skali 1:10 000 (arkusze: N-34-127-A-c4 Serock, N-34-127-A-d3 Kuligów, N-34-127-A-d4 Ludwików), który został także zdygitalizowany i zapisany $\mathrm{w}$ postaci wektorowej warstwy informacyjnej. Wszystkie prace, w tym analizę, interpretację oraz wizualizację wyników, przeprowadzono za pomocą pakietu oprogramowania ArcGIS 10.1 i 10.2.1 o najwyższej dostępnej funkcjonalności (ArcInfo). Uproszczony schemat prac przedstawiono na rycinie 2 .

\section{Wyniki badań}

Zidentyfikowane zmiany morfologii strefy korytowej omówiono w trzech przedziałach czasowych: 43-letnim (lata 1891-1934), 40-letnim (lata 1934-1974) i 36-letnim (1974-1910). Z powodu zróżnicowanego stopnia naturalności na potrzeby analizy wyników wydzielono poddany większej antropopresji odcinek A (12.-17. km) i bardziej naturalny odcinek B (17.-22. km) (ryc. 1). Szczegółowe wyniki omówiono oddzielnie dla każdego z nich. Wyniki analizy ilościowej (tab. 2) przedstawiono dla całego odcinka ze względu na jego niewielką długość $(10 \mathrm{~km})$.

\section{Zmiany morfologii strefy korytowej dolnego Bugu w latach 1891-1934}

W najstarszym z analizowanych okresów (1891-1934), a więc liczącym 44 lata, na odcinku A nastąpiły największe zmiany układu koryta. Dominowały procesy akumulacyjne, które doprowadziły do zwężenia koryta Bugu na całej niemal długości. Zmianie uległo położenie największej na badanym odcinku wyspy o długości ponad 2 $\mathrm{km}$ i maksymalnej szerokości $0,4 \mathrm{~km}$. W wyniku zaniku powiązanego z nią koryta bocznego o długości około 1,4 $\mathrm{km}$ i szerokości $40 \mathrm{~m}$ wyspa ta przesunęła się około $1 \mathrm{~km}$ w górę rzeki i połączyła $\mathrm{z}$ drugą co do wielkości wyspą zlokalizowaną na wysokości miejscowości Jackowo Dolne (15.-16. km). W niektórych miejscach główne koryto zmniejszyło swoją szerokość niemal o połowę (np. z 405 do $210 \mathrm{~m}$ na wysokości 16 . $\mathrm{km}$, czy też z 400 do $200 \mathrm{~m}$ na wysokości 13,1. km) (ryc. 3a).
Jednocześnie w latach 1891-1934 na odcinku A zaobserwowano dwa przebiegające równocześnie procesy. Pierwszy z nich to zanikanie koryt bocznych i ich przekształcanie się w odcięte od głównego koryta obniżenia wypełnione wodą. Drugie zaś to zanikanie wypełnionych wodą obniżeń o takiej genezie. Na uwagę zasługuje fakt, że w stosunku do skali akumulacji procesy erozji bocznej w strefie głównego koryta wydają się stosunkowo mało intensywne. Strefy jej występowania zidentyfikowano tylko lokalnie, a maksymalny zarejestrowany w ciągu 43 lat zasięg erozji bocznej wyniósł zaledwie $45 \mathrm{~m}$ (ryc. 3a).

W latach 1891-1934 na odcinku B, podobnie jak na odcinku A, nastąpiły największe w całym badanym okresie zmiany układu koryta. Dominującą tendencją było zmniejszenie się jego krętości przy jednoczesnym zmniejszeniu (choć nie tak znacznym jak na odcinku A) szerokości. Najistotniejszą zmianą był zanik meandra o szerokości $200 \mathrm{~m}$ zlokalizowanego w środkowej części odcinka (między 18,7. a 20,5. km). Pozostałością po tej formie jest ciąg starorzeczy. W konsekwencji zaniku meandra w obręb równi zalewowej włączona została największa na badanym odcinku rzeki wyspa o długości 1,6 km i maksymalnej szerokości $780 \mathrm{~m}$ (ryc. 3b). Zmniejszeniu krętości (prostowaniu się) głównego koryta towarzyszyła erozja boczna prawego brzegu oraz akumulacja dominująca na całej niemal długości lewego brzegu, co spowodowało przesunięcie się koryta na północ. Maksymalną wartość erozji bocznej zarejestrowano lokalnie na wysokości $21,2 \mathrm{~km}$. Wyniosła ona $150 \mathrm{~m}$ i była prawdopodobnie związana z powstaniem w korycie wyspy o szerokości 150 i długości około $500 \mathrm{~m}$, rozdzielającej je na dwa ramiona o podobnej szerokości.

Jednocześnie, szczególnie w lewobrzeżnej części równi zalewowej, następował zanik wypełnionych wodą obniżeń - starorzeczy, fragmentów koryt bocznych i rynien erozyjnych przepływów wezbraniowych (ryc. 3b).

Dominację procesów akumulacyjnych w latach 1891-1934 potwierdzają pomiary powierzchni wybranych form rzeźby. Na badanym odcinku (12.-22. km) powierzchnia koryta zmniejszyła się o niemal $24 \%$, co było największą wartością w całym analizowanym okresie. Jednocześnie powierzchnia wysp zwiększyła się o $12,8 \%$, a sumaryczna powierzchnia wypełnionych wodą obniżeń w proksymalnej części równi zalewowej zmalała o $24,5 \%$ (tab. 2). 


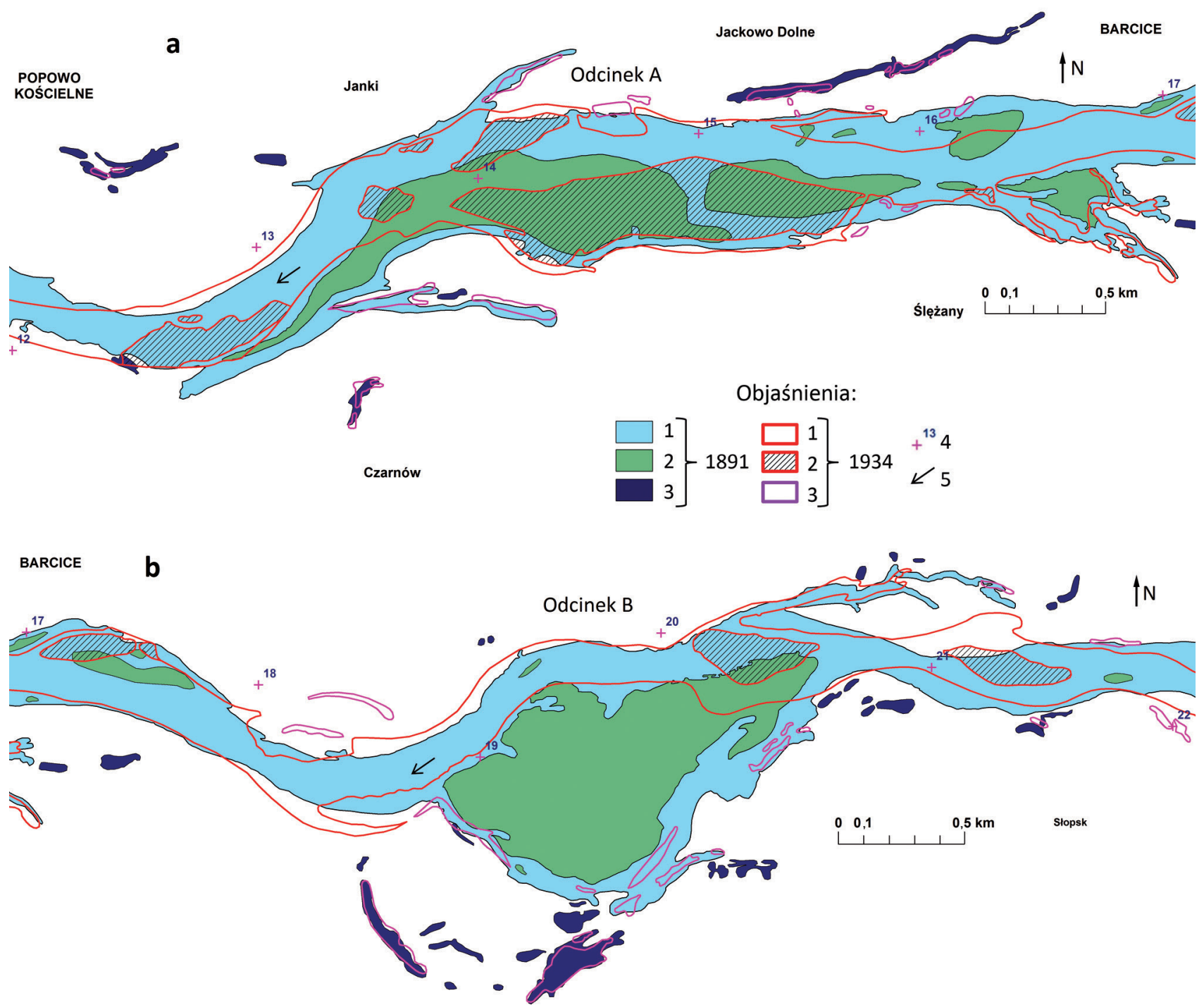

Ryc. 3. Zmiany morfologii strefy korytowej Bugu w latach 1891-1934 na odcinku A (a) i B (b)

1 - koryto, 2 - wyspy, 3 - obniżenia wypełnione wodą (zanikające koryta boczne, rynny erozyjnych przepływów wezbraniowych, starorzecza), 4 - kilometraż, 5 - kierunek biegu rzeki

Fig. 3. Dynamics of the Bug river channel during 1891-1934 period - reaches A (a) and B (b)

1 - channel, 2 - islands, 3 - water bodies (side arms, erosional pathways of overbank flow, oxbow lake), 4 - kilometrage of the Bug waterway, 5 - river flow direction

\section{Zmiany morfologii strefy korytowej dolnego Bugu w latach 1934-1974}

W czasie kolejnych 40 lat (1934-1974) na odcinku A nastąpiło dalsze zwężenie się głównego koryta. Na niemal całej długości zmniejszyło ono szerokość średnio od około 25 do 50\%. Największe zmiany zidentyfikowano na wysokości miejscowości Jackowo Dolne (15,2. km). W strefie tej szerokość koryta zmalała z 250 do $90 \mathrm{~m}$. Główne koryto zwiększyło swoją szerokość jedynie na stosunkowo krótkim odcinku pomiędzy 12,4.-12,6. km, prawdopodobnie $\mathrm{w}$ wyniku zwiększenia się rozmiarów wyspy zlokalizowanej w jego lewobrzeżnej części i związanej z tym erozji prawego brzegu. Jej maksymalny zasięg wyniósł około $110 \mathrm{~m}$. Przesunięcie się głównego koryta o około $50 \mathrm{~m}$ na północ nastąpiło także pomiędzy 16 . a $17 . \mathrm{km}$.
Jednocześnie ze zwężaniem się głównego koryta na obszarze równi zalewowej zaobserwowano powstawanie i rozwój ciągów obniżeń, których elementami były wypełnione wodą fragmenty dawnych koryt bocznych i rynny erozyjne przepływów wezbraniowych. Proces ten doprowadził do połączenia się niektórych obniżeń z głównym korytem i powstania długich, wąskich, współkształtnych do niego form, w czasie wezbrań pełniących prawdopodobnie rolę uprzywilejowanych stref przepływu wód wezbraniowych. Opisane powyżej zmiany ilustruje rycinie 4a.

$\mathrm{Na}$ odcinku B w latach 1934-1974 główne koryto zmieniło przebieg na całej niemal długości przy jednoczesnym dalszym zmniejszeniu swojej szerokości. Związane to było głównie z zanikiem wysp od długości powyżej 0,5. km (na wysokości 17.-17,5., 20.-20,5. i $21 .-21,5 . \mathrm{km}$ ) oraz powstaniem nowej, największej na badanym odcinku mezoformy korytowej w rejonie 18.- 


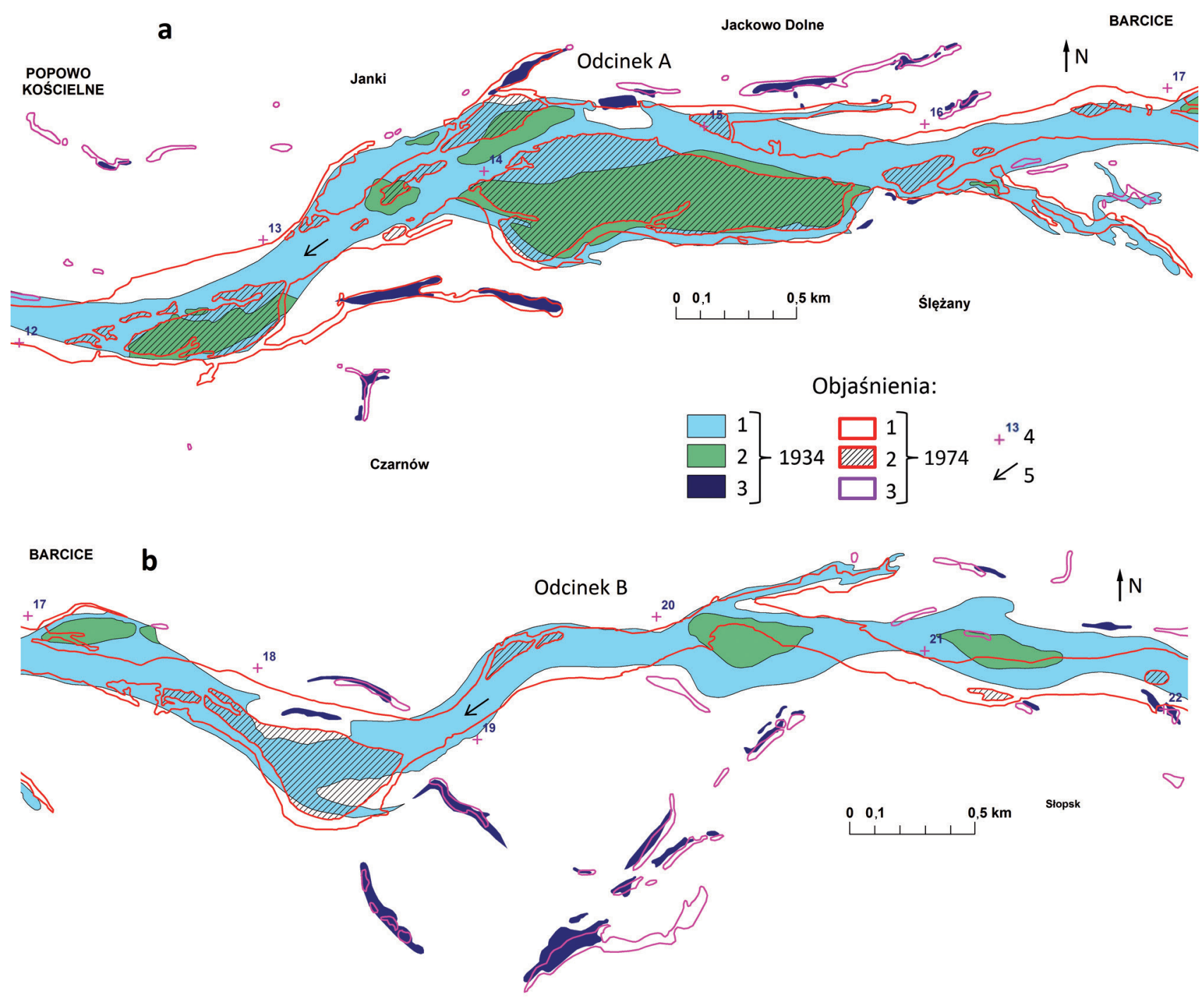

Ryc. 4. Zmiany morfologii strefy korytowej Bugu w latach 1934-1974 na odcinku A (a) i odcinku B (b)

1 - koryto, 2 - wyspy, 3 - obniżenia wypełnione wodą (zanikające koryta boczne, rynny erozyjnych przepływów wezbraniowych, starorzecza, 4 - kilometraż, 5 - kierunek biegu rzeki

Fig. 4. Dynamics of the Bug river channel during 1934-1974 period - reaches A (a) and B (b)

1 - channel, 2 - islands, 3 - water bodies (side arms, erosional pathways of overbank flow, oxbow lake), 4 - kilometrage of the Bug waterway, 5 - river flow direction

19. km. W rejonie tym, w miejscu dawnego głównego koryta, powstała wyspa o długości 700 i maksymalnej szerokości $350 \mathrm{~m}$. Spowodowało to przesunięcie się koryta Bugu o około $180 \mathrm{~m}$ na północ, w miejsce dawnego ciągu obniżeń (rynny erozyjnej przepływów wezbraniowych) zlokalizowanego w prawobrzeżnej części równi zalewowej (ryc. 4 B).

W latach 1934-1974 na odcinku B w proksymalnej części równi zalewowej zaobserwowano dalszą ewolucję obniżeń wypełnionych wodą powiązanych genetycznie z działalnością wód wezbraniowych. Niektóre z wypełnionych wodą ciągów obniżeń uległy zanikowi, niektóre zaś zwiększyły swoje rozmiary. Zarówno w lewobrzeżnej, jak i prawobrzeżnej części równi zalewowej zidentyfikowano także nowe formy o tej genezie.

W latach 1934-1974 powierzchnia koryta na całym badanym odcinku (12.-22. km) zmniejszyła się o kolejne
10,3\%. Zmiana ta była jednak niemal dwukrotnie mniejsza niż w poprzednio analizowanym okresie (1891-1934) (tab. 2). Zwiększyło się natomiast ponad dwukrotnie tempo przyrostu powierzchni wysp. Wzrosła ona o $22,9 \%$. Sumaryczna powierzchnia wypełnionych wodą obniżeń w proksymalnej części równi zalewowej zwiększyła się o $15,7 \%$ (tab. 2).

\section{Zmiany morfologii strefy korytowej dolnego Bugu w latach 1974-2010}

W kolejnych 36-letnim okresie (1974-2010) układ koryta Bugu charakteryzował się dużą stabilnością. Główne koryto na całej niemal długości przesunęło się na północ, lecz były to zmiany niewielkie, wynoszące średnio około 15-20 m, lokalnie tylko dochodzące do $40 \mathrm{~m}$ (ryc. 5a). Dość stabilne były wszystkie mezoformy korytowe łącz- 

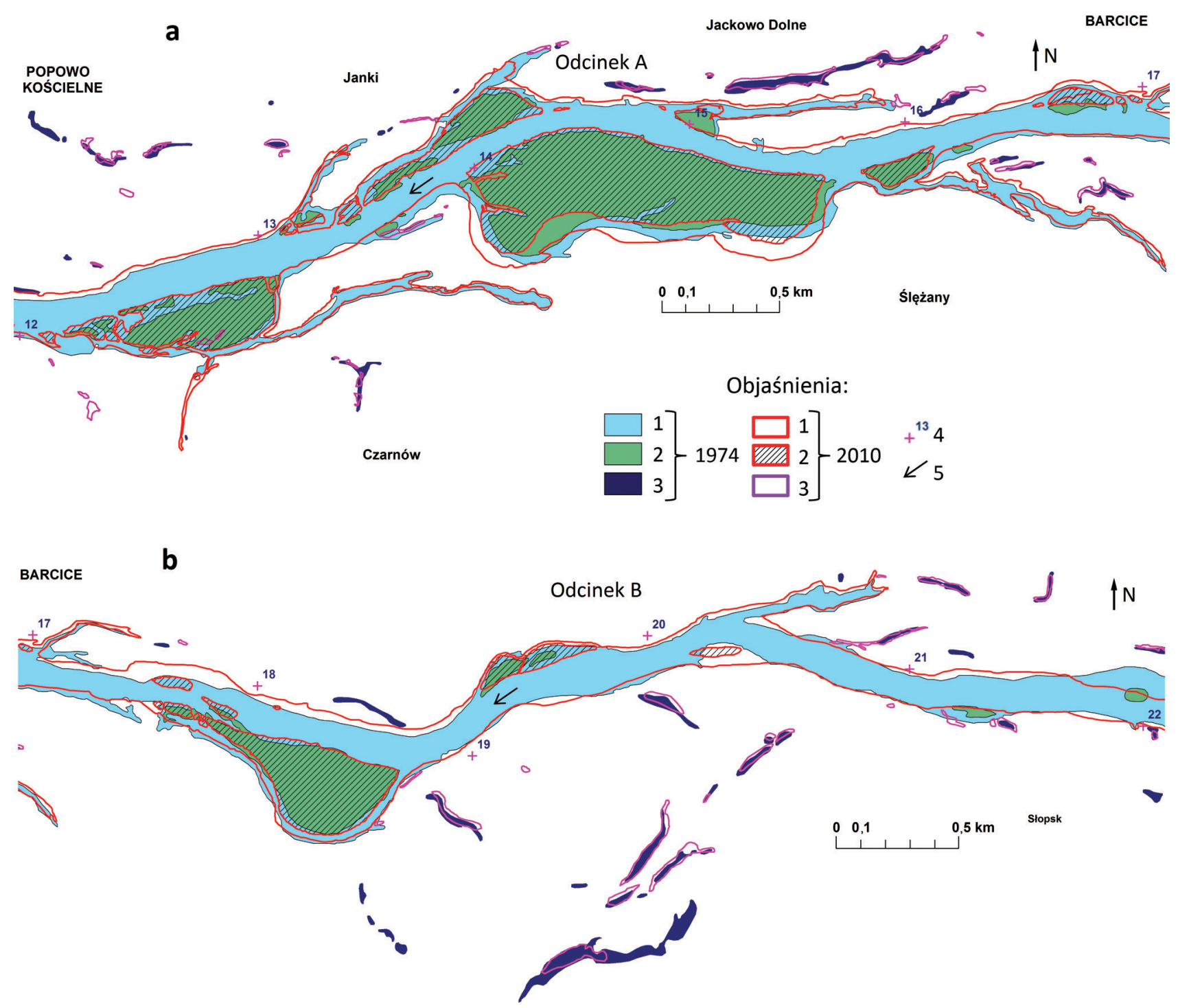

Ryc. 5. Zmiany morfologii strefy korytowej Bugu w latach 1974-2010 na odcinku A (a) i odcinku B (b)

1 - koryto, 2 - wyspy, 3 - obniżenia wypełnione wodą (zanikające koryta boczne, rynny erozyjnych przepływów wezbraniowych, starorzecza), 4 - kilometraż, 5 - kierunek biegu rzeki

Fig. 5. Dynamics of the Bug river channel during 1974-2010 period - reaches A (a) and B (b)

1 - channel, 2 - islands, 3 - water bodies (side arms, erosional pathways of overbank flow, oxbow lake), 4 - kilometrage of the Bug waterway, 5 - river flow direction

nie $\mathrm{z}$ największą, położoną $\mathrm{w}$ centralnej części odcinka wyspą o długości około 1,5 km i szerokości $430 \mathrm{~m}$.

Nadal występował, choć wykazywał zdecydowanie mniejszą dynamikę, rozwój ciągów obniżeń, których elementami były głównie fragmenty dawnych koryt bocznych i rynny erozyjne przepływów wezbraniowych.

W latach 1974-2010 także na odcinku B zmiany układu strefy korytowej były niewielkie. Stabilny był zarówno układ głównego koryta, jak i największa na badanym odcinku wyspa w rejonie $18 .-19$. km. Zmiany położenia koryta, które wiązać można z erozją boczną, nie przekraczały $50 \mathrm{~m}$. Największe zmiany układu głównego koryta wystąpiły lokalnie w miejscach powstawania lub zanikania wysp, lecz były to formy o rozmiarach dużo mniejszych niż analizowane wcześniej. Przykładem takich zmian może być powstanie wyspy w rejonie 20,2. km czy też zanik wysp między 21. a 22. km (ryc. 5b).
W analizowanym okresie zaobserwowano także zmniejszanie się rozmiarów i zanik wypełnionych wodą obniżeń, głównie starorzeczy zlokalizowanych w lewobrzeżnej części równi zalewowej.

$\mathrm{Na}$ całym badanym odcinku rzeki w latach 19742010 powierzchnia koryta Bugu zmniejszyła się zaledwie o $0,9 \%$, a wyspy wzrosła o 10,5\% (tab. 2). Dość znacznie, bo o $32,6 \%$, zmniejszyła się jednocześnie powierzchnia obniżeń wypełnionych wodą. Główną tego przyczyną był zanik starorzeczy położonych w lewobrzeżnej części równi zalewowej odcinka B (tab. 2, ryc. 5b).

\section{Zmiany morfologii strefy korytowej dolnego Bugu w latach 2010-2013 (odcinek B)}

Analiza zobrazowania satelitarnego VHRS z lipca 2013 r. oraz wykonane w tym okresie prace tereno- 
we potwierdziły poprawność wcześniejszej interpretacji materiałów teledetekcyjnych. W okresie trzech lat (2010-2013) nie zaobserwowano istotnych zmian układu analizowanych form oprócz dalszego zmniejszenia się powierzchni starorzeczy w lewobrzeżnej części równi zalewowej. Co prawda zarejestrowano niewielkie, nieprzekraczające $5 \mathrm{~m}$, przesunięcie się głównego koryta na północ, lecz jest to wartość na tyle mała, że wynikać może np. z błędów związanych z kalibracją materiałów rastrowych.

\section{Dyskusja}

W wyniku analizy porównawczej materiałów kartograficznych i teledetekcyjnych obejmujących ostatnie 122 lata ewolucji koryta dolnego Bugu i wybranych, powiązanych z jego oddziaływaniem form rzeźby, zidentyfikowano tendencje charakterystyczne dla morfogenezy tego odcinka rzeki. Zarówno na częściowo uregulowanym w latach 60. XX w. odcinku A, jak i na cechującym się wysokim stopniem naturalności odcinku B w całym analizowanym okresie dominowały procesy akumulacyjne, choć ich nasilenie, największe w latach 1891-1934, ulegało wyraźnemu spadkowi (ryc. 3-5, tab. 2). Efektem tych procesów było ponaddwukrotne, a na niektórych odcinkach (np. w rejonie 16,2.-16,5. km) niemal czterokrotne zmniejszenie się szerokości głównego koryta. Tendencję tę potwierdzają także zmiany powierzchni analizowanych form. W ciągu 119 lat (1891-2010) powierzchnia koryta Bugu zmniejszyła się o ponad $30 \%$ przy jednoczesnym dwukrotnym zwiększeniu się sumarycznej powierzchni wysp, a powierzchnia obniżeń wypełnionych wodą w proksymalnej części równi zalewowej zmniejszyła się o około $40 \%$.

Analiza geoprzestrzenna zgromadzonych materiałów pozwala przypuszczać, że najważniejszym czynnikiem odpowiedzialnym za zmiany układu koryta dolnego Bugu nie była erozja boczna, lecz procesy zachodzące w warunkach przepływów pozakorytowych. Wydaje się, że można do nich zaliczyć stopniowe zanikanie koryt bocznych i powiązane $\mathrm{z}$ nim włączanie $\mathrm{w}$ obszar równi zalewowej utrwalonych roślinnością wysp o bardzo dużych (często przekraczających kilometr) rozmiarach, a także proces odwrotny - wykorzystywanie przez wody wezbraniowe jako strefy uprzywilejowanego przepływu ciągów obniżeń o różnej genezie, czego końcowym efektem jest powstawanie koryt bocznych „odcinających” fragmenty równi zalewowej i powstawanie nowych wysp. Weryfikacja tych przypuszczeń wymaga jednak szczegółowych badań terenowych, które są planowane w najbliższym czasie. Na uwagę załuguje fakt, że podobne procesy (cykliczne koncentrowanie się przepływów pozakorytowych w strefie lokalnych obniżeń równiny zalewowej np. w systemach długich, połączonych ze sobą paleokoryt) zarejestrowano też w Podlaskim Przełomie Bugu (Kusznerczuk, Hołub 2008).

Opisywane powyżej zjawiska wiązać można ze specyfiką hydrologiczną doliny dolnego Bugu oraz z morfo-

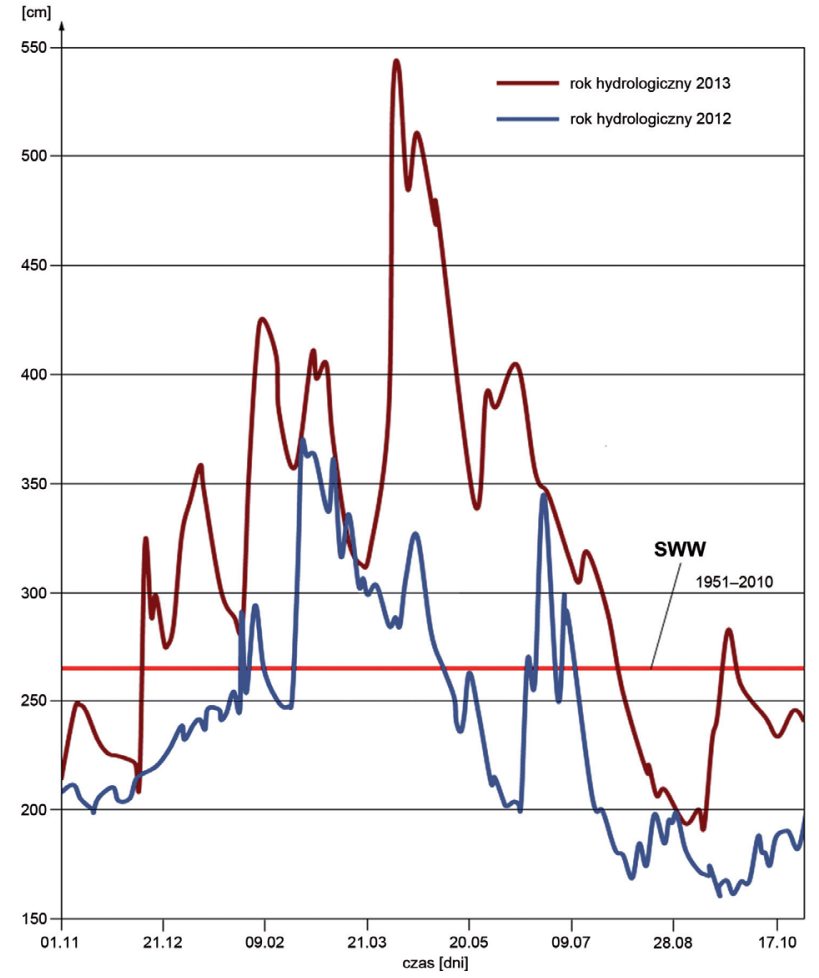

Ryc. 6. Stany wody na posterunku wodowskazowym Wyszków (34,2. km) w latach 2012-2013 (dane IMGW)

Fig. 6. The water stages at Wyszków gauge station $(34,2 . \mathrm{km})$ during the period 2012-2013 (IMGW data)

logią równi zalewowej. Rzeka na tym odcinku charakteryzuje się dużą zmiennością zarówno przepływów, jak i stanów wody, co jest związane $\mathrm{z}$ występowaniem co najmniej dwu wezbrań (wiosennego roztopowego oraz opadowego latem i jesienią) (Ostrowski 2003) i letnio-jesiennych niżówek hydrologicznych (Mierkiewicz, Sasim 2003). Przebieg wezbrań jest nietypowy ze względu na długotrwały spływ wód wezbraniowych. Również niżówki charakteryzują się stosunkowo długim okresem trwania i znaczną częstością występowania (Michalczyk, Sobolewski 2002, Mierkiewicz, Sasim 2003). Ponieważ analizowana część równi zalewowej wyniesiona jest zaledwie od około 0,4 do 0,7 m ponad SSW mamy do czynienia z cyklicznie powtarzającymi się i trwającymi dość długo kluczowymi dla morfogenezy badanego odcinka okresami przepływu pozakorytowego oraz niżówkami. Stany średnie, w których dominujacą rolę odgrywałaby erozja boczna trwają stosukowo krótko. Tendencję taką potwierdzają przykładowe stany wody zarejestrowane na posterunku wodowskazowym Wyszków $(34,2$. km) (ryc. $6)$.

W wyniku przeprowadzonych badań stwierdzono także, że wpływ wykonanej w latach 60. regulacji koryta Bugu czy cofki Jeziora Zegrzyńskiego (odcinek A) na morfogenezę badanego odcinka koryta tej rzeki w dhuższym (kilkudziesięcioletnim) przedziale czasowym był niewielki. Ewolucja układu koryta na obu odcinkach przebiegała podobnie. Może to być związane z małą trwałością zabudowy hydrotechicznej odcinka $\mathrm{A}$, a więc krótkim okresem jej oddziaływania na procesy korytowe. 
Przypuszczać można, że w najbliższej przyszłości na badanym odcinku Bugu morfologia strefy korytowej charakteryzować się będzie względną stabilnością, o ile nie wystąpią zjawiska ekstremalne, takie jak katastrofalne wezbrania roztopowe lub zatorowe. Przypuszczenia takie potwierdza analiza zobrazowań satelitanych VHR.

\section{Wnioski}

1. Na obu odcinkach dolnego Bugu (A i B) największe zmiany morfologii strefy korytowej wystąpiły w latach 1981-1934, a najmniejsze w latach 1974-2010 (2013).

2. Zarówno na odcinku A, jak i B w latach 1891-1934 dominowały procesy akumulacyjne, czego efektem było zmniejszenie się powierzchni i szerokości głównego koryta przy jednoczesnym zwiększeniu się powierzchni wysp. Trend ten utrzymał się w kolejnych analizowanych okresach, lecz dynamika zmian malała.

3. Analiza materiałów kartograficznych i teledetekcyjnych pozwala przypuszczać, że na badanym odcinku Bugu głównymi czynnikami powodującymi zmiany morfologii strefy korytowej są:

- zanikanie koryt bocznych i powiązane z nim włączanie wysp w obszar równi zalewowej,

- rozwój wypełnionych wodą ciągów obniżeń (uprzywilejowanych stref przepływu wód wezbraniowych), w których skład wchodzą fragmenty dawnych koryt bocznych, rynny erozyjne przepływów wezbraniowych i starorzecza, a w konsekwencji powstawanie nowych wysp.

Mniejsze znaczenie ma erozja boczna.

4. Nie stwierdzono wyraźnego wpływu czynników antropogenicznych, takich jak regulacja koryta czy cofka Jeziora Zegrzyńskiego, na morfogenezę badanego odcinka koryta rzeki. Ewolucja układu koryta zarówno na poddanym większej antropopresji odcinku A, jak i bardziej naturalnym odcinku B przebiegała podobnie.

5. Przypuszczać można, że w najbliższej przyszłości na badanym odcinku morfologia strefy korytowej dolnego Bugu charakteryzować się będzie względną stabilnością. Istotnym elementem w przewidywaniu dalszych kierunków jej rozwoju powinna być analiza zmian form erozyjnych w strefach uprzywilejowanych przepływów wód wezbraniowych. Ich morfodynamika jest ważnym wskaźnikiem mogących nastąpić zmian układu koryta.

\section{Podziękowania}

Autorzy składają podziękowanie dwóm anonimowym recenzentom za wnikliwe i cenne uwagi do pierwotnej wersji artykułu.

\section{Literatura}

Falkowski E., 1971. Historia i prognoza rozwoju koryta wybranych odcinków rzek nizinnych Polski. Biuletyn Geologiczny, Wydział Geologii Uniwersytetu Warszawskiego 12: 5-122.

Falkowski T., 2006. Naturalne czynniki stabilizujące wybrane odcinki strefy korytowej Wisły środkowej. Wydawnictwo SGGW, Warszawa.

Falkowski T., Ostrowski P., 2010. Morfogeneza powierzchni tarasu zalewowego Wisły w okolicach Magnuszewa w obrazie zdjęć satelitarnych i lotniczych. Infrastruktura i Ekologia Terenów Wiejskich 9: 89-100.

Gromiec M., 2003. Zbiornik Zegrzyński. W: J. Dojlido, W. Kowalczewski, R. Miłaszewski, J. Ostrowski (red.), Rzeka Bug - zasoby wodne i przyrodnicze. Cz. III. Zagospodarowanie zlewni. IMGW, Warszawa.

GUGiK [Główny Urząd Geodezji i Kartografii], 2013. Geoportal krajowy. Online 4.11.2014 http://geoportal.gov.pl.

Kondracki J., 2009. Geografia Regionalna Polski. PWN. Warszawa.

Kusznerczuk M., Hołub B., 2008. Rola powodzi w kształtowaniu równiny zalewowej doliny Bugu pod Janowem Podlaskim (Podlaski Przełom Bugu). Landform Analysis 8: 49-52.

Magnuszewski A., 2011. Analiza wpływu akumulacji rumowiska w strefie oddziaływania zbiorników na bezpieczeństwo powodziowe w regionie. Określenie kryteriów wyboru miejsc przeprowadzenia prac pogłębiarskich. Ekspertyza w ramach Programu Bezpieczeństwa Powodziowego w Regionie Wodnym Środkowej Wisły. Warszawa.

Michalczyk Z., Sobolewski W., 2002. Charakterystyka hydrologiczna dorzecza Bugu. Annales Universitatis Mariae Curie-Skłodowska, sectio B LVII(7).

Mierkiewicz M., Sasim M., 2003. Warunki formowania się odpływu powodzie i susze. W: J. Dojlido, W. Kowalczewski, R. Miłaszewski, J. Ostrowski (red.), Rzeka Bug - zasoby wodne i przyrodnicze. Cz. IV. Środowisko przyrodnicze. IMGW, Warszawa.

Mojski J.E., 2005. Ziemie polskie w czwartorzędzie. Zarys Morfogenezy. PIG, Warszawa.

Niedbała J., Ceran M., Dominikowski M., 2012. Określenie warunków przejścia wielkich wód w rzekach regionu wodnego Wisły środkowej z uwzględnieniem wielkości przepływów charakterystycznych w profilu Zawichost. Ekspertyza IMGW-PIB. Warszawa.

Ostrowski J., 2003. Dynamika i wieloletnie tendencje zmian zasobów wodnych. W: J. Dojlido, W. Kowalczewski, R. Miłaszewski, J. Ostrowski (red.), Rzeka Bug - zasoby wodne i przyrodnicze. Cz. IV. Środowisko przyrodnicze. IMGW, Warszawa.

Ostrowski P., 2011. Wykorzystanie wysokorozdzielczych zdjęć satelitarnych do identyfikacji form rzeźby wybranego fragmentu doliny Bugu. Praca doktorska. Szkoła Główna Gospodarstwa Wiejskiego w Warszawie.

Projekt mapywig.org, 2014. Archiwum Map Wojskowego Instytutu Geograficznego 1919-1939. Online: http://polski.mapywig.org/news. php - 04.11.2014.

Urban D., Wójciak H., 2003. Roślinność ekosystemów wodnych. W: J.Dojlido, W.Kowalczewski, R.Miłaszewski, J.Ostrowski (red.), Rzeka Bug zasoby wodne i przyrodnicze. Część IV - Środowisko przyrodnicze. IMGW Warszawa.

Wierzbicki G., Ostrowski P., Mazgajski M., Bujakowski F., 2013. Using VHR multispectral remote sensing and LIDAR data to determine the geomorphological effects of overbank flow on a floodplain (the Vistula River, Poland). Geomorphology 183: 73-81.

Wojciechowski K., 2003. Europejski korytarz ekologiczny doliny Bugu. W: J. Dojlido, W. Kowalczewski, R. Miłaszewski, J. Ostrowski (red.), Rzeka Bug - zasoby wodne i przyrodnicze. Cz. IV. Środowisko przyrodnicze. IMGW, Warszawa.

Zieliński J., Narowski S., 2003. Zabudowa regulacyjna. W: J. Dojlido, W. Kowalczewski, R. Miłaszewski, J. Ostrowski (red.), Rzeka Bug - zasoby wodne i przyrodnicze. Cz. III. Zagospodarowanie zlewni. IMGW. Warszawa 2003. 